\title{
The influence of prior experience with artificial fruits on the ovipositioning behavior of Anastrepha fraterculus (Diptera, Tephritidae)
}

\author{
Patrícia L. F. Gregório, Josué Sant’Ana, Luiza R. Redaelli \& Thiago D. N. Idalgo
}

Programa de Pós-Graduação em Fitotecnia, Departamento de Fitossanidade, Universidade Federal do Rio Grande do Sul (UFRGS). Av. Bento Gonçalves, 7712, 91540-000 Porto Alegre, RS, Brasil. (patriciafgregorio@yahoo.com.br; josue.santana@ufrgs.br; leredael@ufrgs.br; della_nina1@yahoo.com.br)

\begin{abstract}
The South American fruit fly, Anastrepha fraterculus (Wiedemann, 1830) (Diptera, Tephritidae), is a leading pest of Brazilian fruit crops. This study evaluated how prior experience with artificial fruits containing peach and/or guabiroba pulp influenced the ovipositing behavior of $A$. fraterculus. Insects 15-21 days old were exposed to four treatments: 1) experience with guabiroba, Campomanesia xanthocarpa O. Berg (Myrtaceae); 2) experience with peach, Prunus persica (L.) Batsch (Chimarrita cultivar; Rosaceae); 3) experience with both fruits; and 4) no experience (naive). Naive females and females experienced with guabiroba pulp and with both fruits (peach and guabiroba) oviposited and showed dragging and puncturing behavior on substrates containing guabiroba, but females that were only exposed to peach pulp did not show a preference for any substrate. The study shows that prior experience with substrate influences ovipositing behavior in A. fraterculus.
\end{abstract}

KEYWORDS. Fruit flies, hosts, learning.

RESUMO. Influência da experiência prévia com frutos artificiais no comportamento de oviposição de Anastrepha fraterculus (Diptera, Tephritidae). A mosca-das-frutas-sul-americana, Anastrepha fraterculus (Wiedemann,1830) (Diptera, Tephritidae) é uma das principais pragas da fruticultura no Brasil. O trabalho objetivou avaliar a influência da experiência prévia com frutos artificiais contendo polpa de pêssego e/ou guabiroba no comportamento de oviposição de A. fraterculus. Foram utilizados insetos entre 15 e 21 dias de idade, expostos a quatro tratamentos: 1) experiência com guabiroba, Campomanesia xanthocarpa O. Berg (Myrtaceae); 2) com pêssego, Prunus persica (L.) Batsch (cultivar Chimarrita) (Rosaceae); 3) com ambos; 4) inexperientes. Fêmeas inexperientes, assim como as experientes com polpa de guabiroba e com ambas (pêssego e guabiroba) ovipositaram e apresentaram comportamentos de arraste e punctura nos substratos que continham guabiroba, porém, as fêmeas previamente expostas somente à polpa de pêssego não apresentaram preferência por qualquer um dos substratos. O presente estudo indica que a experiência prévia com o substrato influencia o comportamento de oviposição de $A$. fraterculus.

PALAVRAS-CHAVE. Mosca-das-frutas, hospedeiros, aprendizagem.

Insects use a variety of sensory capabilities to orient themselves and recognize appropriate hosts (LOAIZA \& CÉSPEDES, 2007). Frugivorous tephritids use visual attributes including color, size, and shape to locate hosts (Cytrynowicz et al., 1982; MCInnis, 1989; Katsoyannos \& Kouloussis, 2001; Drew et al., 2003; Piñero et al., 2006; LóPEZ-GUILLÉN et al., 2009), in addition to chemical stimuli in the form of nutrients (JoACHIM-Bravo et al., 2001a) and volatile substances (CoRNelius et al., 2000; MALO et al., 2005; SiderhURST \& JANG, 2006).

Researchs with tephritids have shown that other factors like experience also play a role in host acceptance, as observed in Ceratitis capitata (Wiedemann, 1824) (JoACHim-Bravo et al., 2001a,b) and Anastrepha ludens (Loew, 1873) (Robacker \& Fraser, 2002, 2005; DíazFleischer \& Aluja, 2003). In Anastrepha species, oviposition is accompanied by a sequence of behaviors: arriving at the fruit (via visual and chemical stimuli); searching (the female walks along the surface of the fruit, touching it with the anterior portion of its head and with ovipositing sheath); puncturing (the aculeus is inserted into the fruit pulp, but the female does not necessarily deposit eggs) and dragging (the female walks along the surface of the fruit with the aculeus extended) (SUGAYAMA \& MALAVASI, 2000). Little is known, however, about the factors that influence the choice of oviposition substrate in Anastrepha fraterculus (Wiedemann, 1830) (Diptera, Tephritidae), and how prior experience might influence the process of host selection.
The South American fruit fly, A. fraterculus, is one of the leading pests of fruit crops in Brazil. Females damage fruits by inserting the aculeus, whether or not they deposit eggs. Larvae form galleries inside fruits, which alters their flavor and compromises crop production and commercialization.

This study assessed how prior experience with artificial fruits influences the ovipositing behavior of A. fraterculus, using a descriptive analysis based on ethograms.

\section{MATERIAL AND METHODS}

The insects used in all trials came from a culture maintained in the laboratory at Departamento de Fitossanidade, Universidade Federal do Rio Grande do Sul (UFRGS). Wild flies were added to this culture in spring and summer months. Adults were maintained in cages measuring $30 \times 20 \times 15 \mathrm{~cm}$, where they received distilled water and a diet composed of sugar, corn gluten, and brewer's yeast (in a 3:1:1 ratio) and vitamin $E$ (adapted from JALDO et al., 2001) placed in Petri dishes measuring $4 \mathrm{~cm}$ diameter $\times 1 \mathrm{~cm}$ high. The artificial fruits used as ovipositing substrate (hemispheric; 3,5 $\mathrm{cm} ø$ ) were made of agar, water, blackberry juice, and methylparaben, wrapped in parafilm following SALLES (1992), and replaced daily. Larvae were fed with an artificial diet of sugar, wheat germ, brewer's yeast, 
methylparaben, sodium benzoate, citric acid, agar and water (adapted from SALLES, 1992).

The pulp of guabiroba fruits (Campomanesia xanthocarpa O. Berg; Myrtaceae) was extracted manually after macerating the fruits. Peach pulp (Prunus persica (L.) Batsch; Chimarrita cultivar - Rosaceae) was extracted with a food processor. Both pulps were obtained without the addition of solvents 24-48 hours after harvest and kept frozen at $-20^{\circ} \mathrm{C}$ until used in the trials. Acidity, degrees Brix and hue angle for the fruits used as a source of pulp were as follows: guabiroba $=$ $\mathrm{pH} 4.71 ;{ }^{\circ}$ Brix $16.75 ;{ }^{\circ}$ Hue 67.95 and peach $=\mathrm{pH} 4.44$; ${ }^{\circ}$ Brix 12.01; ${ }^{\circ} \mathrm{Hue} 50.28$.

The experiment was carried out with four groups of flies, each composed of 25 couples 15-21 days old. Flies were divided into plastic cages measuring $16 \mathrm{~cm}$ in diameter and $7 \mathrm{~cm}$ high in such a way that each cage held five couples.

Experienced females were those which had been previously exposed (72 hours) to the same ovipositing based on known formulations used in mass-rearing of A. frateculus (SALLES, 1992) as follows: one of the four groups of insects was exposed to an artificial fruit containing guabiroba pulp, one group exposed to an artificial fruit containing peach pulp, and one group exposed simultaneously to an artificial fruit with guabiroba pulp and an artificial fruit with peach pulp. The fourth group had no prior contact with ovipositing substrates and was considered naive. Immediately after the exposure period, the surviving females of each group (exposed to guabiroba, $\mathrm{n}=23$; peach, $\mathrm{n}=20$; both, $\mathrm{n}$ $=22$; naive, $\mathrm{n}=20$ ) were tested individually in plastic trays "trial areas" (11 length x 3.5 width x 11 height $\mathrm{cm}$ ) covered with PVC film.

The insects were acclimated for 30 minutes in the trial area before the experiment began. Each female was then offered two artificial fruits, one with guabiroba pulp and one with peach pulp, located close to a light source, in order to stimulate oviposition. All experiments were carried out at $25^{\circ} \pm 2^{\circ} \mathrm{C}, 65-75 \%$ R.H. and with approximately $5000 \mathrm{Lx}$.

The behavior of each insect was observed inperson, continually, for 30 minutes (focal animal sampling) and the data recorded using Etholog 2.2 software. Bioassays were carried out between 10 a.m. and 3 p.m., at the maximum oviposition period (MALAVASI et al., 1983). The behavioral categories assessed were: inspecting (walking on the fruit or touching its surface with mouthparts); dragging (dragging the ovipositor over the surface of the fruit); puncturing (inserting the aculeus into the fruit); resting (motionless on the fruit without touching it with mouthparts) (SugaYAma \& MALAVASI, 2000). Insects that were not on the fruits were designated as "trial area" in the ethogram. The criteria used to assess behaviors were frequency and behavioral sequence. The proportion of females that oviposited on the artificial fruits in each treatment was also recorded.

The repetition of a single behavior (self-transition) was not included in the records to avoid the possible influence in the relative weight of transitions between behaviors. Data were analyzed with Chi-squared tests $(\alpha=0.05)$ and ethograms were constructed for each of the four groups of insects.

\section{RESULTS AND DISCUSSION}

Females with prior experience of substrates containing peach pulp showed lower rates of dragging, puncturing on fruits with guabiroba pulp than females with prior experience of substrate containing guabiroba pulp. Females with prior experience of peach pulp showed no preference for either substrate, while all other groups preferred to puncture and oviposit on substrates containing guabiroba (Tab. I; Fig. 1).

Experience both with guabiroba (Fig. 2) and peach (Fig. 3) increased acceptance (dragging and puncturing). In both treatments, the proportion of females showing such behaviors was higher than that

Tab. I. Proportions of Anastrepha fraterculus (Wiedemann, 1830) females showing behavioral responses (inspecting, dragging, puncturing, and resting) on artificial fruits containing peach and guabiroba pulp, for both naive and experienced flies. Values with different letters in the treatment columns are significantly different $\left(\chi^{2}, \mathrm{P}<0.05\right)$.

\begin{tabular}{|c|c|c|c|c|c|c|}
\hline \multirow{2}{*}{$\mathrm{n}$} & \multicolumn{2}{|c|}{ Ovoposition substrate } & \multicolumn{4}{|c|}{ Behavioral categories } \\
\hline & Prior experience (3 days) & Treatment & Inspecting & Dragging & Puncturing & Resting \\
\hline \multirow{2}{*}{23} & \multirow{2}{*}{ Guabiroba } & Guabiroba & $91.3 \mathrm{a}$ & $69.6 \mathrm{a}$ & $69.6 \mathrm{a}$ & $52.2 \mathrm{a}$ \\
\hline & & Peach & $69.6 \mathrm{~b}$ & $21.8 \mathrm{~b}$ & $17.4 \mathrm{~b}$ & $13 \mathrm{~b}$ \\
\hline \multirow{2}{*}{20} & \multirow{2}{*}{ Peach } & Guabiroba & $90 \mathrm{a}$ & $60 \mathrm{a}$ & $60 \mathrm{a}$ & $60 \mathrm{a}$ \\
\hline & & Peach & $75 \mathrm{~b}$ & $55 \mathrm{a}$ & $55 \mathrm{a}$ & $40 \mathrm{~b}$ \\
\hline \multirow{2}{*}{22} & \multirow{2}{*}{ Guabiroba and Peach } & Guabiroba & $100 \mathrm{a}$ & $54.5 \mathrm{a}$ & $54.5 \mathrm{a}$ & $68.2 \mathrm{a}$ \\
\hline & & Peach & $95.5 \mathrm{a}$ & $40.9 \mathrm{a}$ & $27.3 \mathrm{~b}$ & $36.4 \mathrm{~b}$ \\
\hline \multirow{2}{*}{20} & \multirow{2}{*}{ Naive } & Guabiroba & $80 \mathrm{a}$ & $30 \mathrm{a}$ & $30 \mathrm{a}$ & $60 \mathrm{a}$ \\
\hline & & Peach & $70 \mathrm{a}$ & $5 \mathrm{~b}$ & $10 \mathrm{~b}$ & $30 \mathrm{~b}$ \\
\hline
\end{tabular}




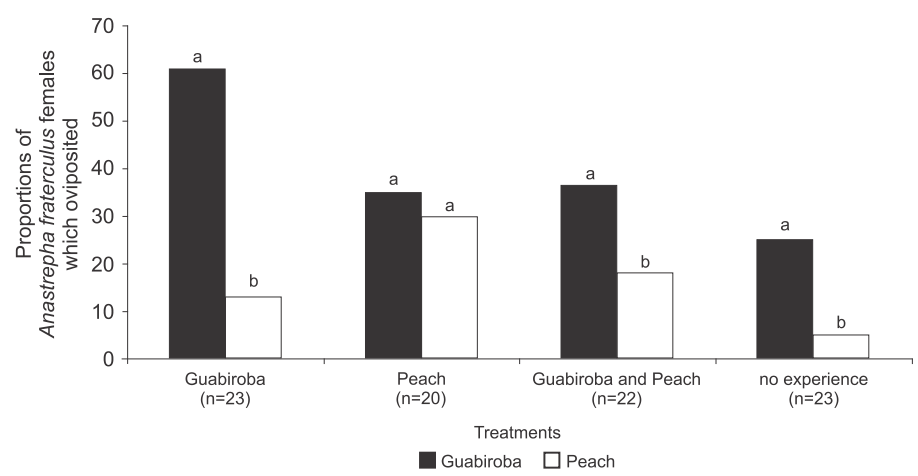

Fig. 1. Proportions of Anastrepha fraterculus (Wiedemann, 1830) females which oviposited on artificial fruits containing peach and guabiroba pulp, for both naive and experienced flies. Values with different letters in the treatment columns are significantly different $\left(\chi^{2}, \mathrm{P}<0.05\right)$.
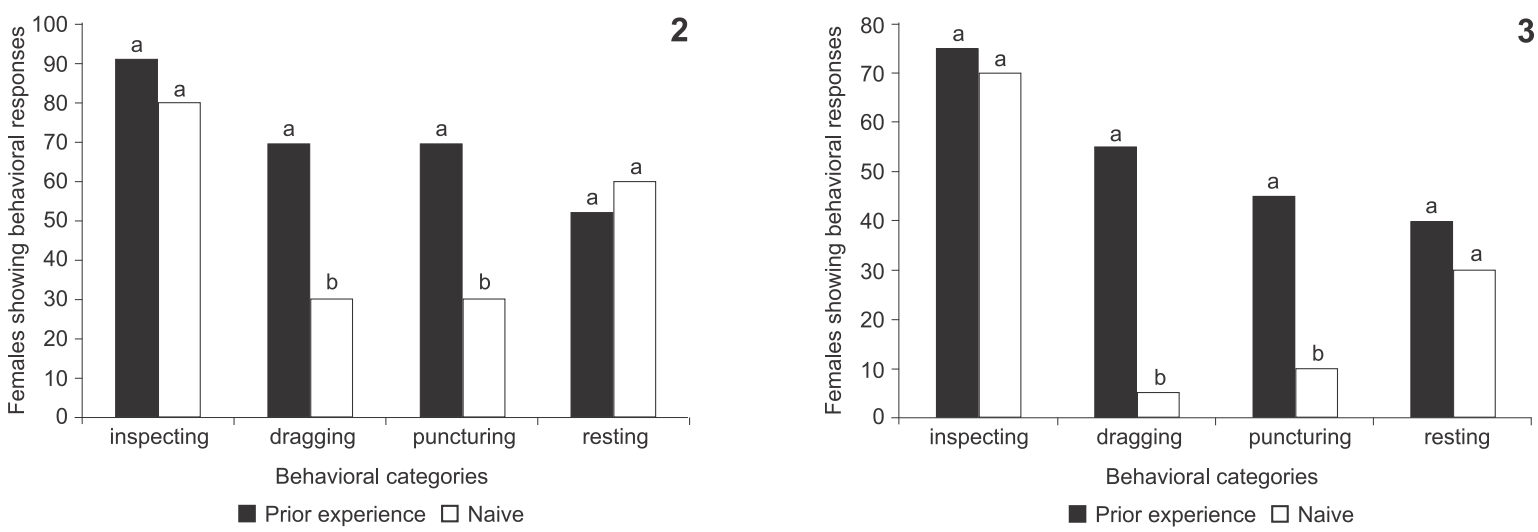

Figs 2, 3. Proportions of Anastrepha fraterculus (Wiedemann, 1830) females that showed assorted behaviors during the experiment: 2, experienced females (guabiroba) and naive females; 3 , experienced females (peach) and naive females. In each graph, similarly colored bars with different letters indicate significantly different values $\left(\chi^{2}, \mathrm{P}<0.05\right)$.

of control (naive) flies $\left(\chi^{2}, \mathrm{P}<0.05\right)$. Females exposed to substrates with peach and guabiroba pulp tended to show the same behavioral sequences (i.e., inspecting, dragging, puncturing, and resting on the chosen fruit (Figs 4 -7).

Despite this similarity, differences in behavioral frequencies were observed between treatments, showing that behavioral responses can vary with experience. Naive females initially inspected both substrates in an indiscriminate manner, but showed a greater frequency of dragging, puncturing and resting on artificial fruits containing guabiroba pulp (Fig. 4). Similar responses were observed when the behavior of insects with prior experience of guabiroba pulp (Fig. 5) was compared with that of insects with prior experience of both pulps (Fig. 6). In these cases, the initial inspecting, dragging, puncturing and resting were more frequent on substrates treated with guabiroba pulp. Females with prior experience of peach pulp, however, inspected the two substrates indiscriminately, but dragged and punctured more frequently on fruits with guabiroba pulp (Fig. 7).

The influence of experience on ovipositing behavior in tephritids has been documented by various authors. JOACHIM-BRAVO et al. (2001a) reported that naive $C$. capitata flies preferred to oviposit on substrates containing citric acid, compared to those containing malic acid. The same pattern of behavior was observed when flies had prior experience of citric acid. However, when flies had prior experience of malic acid, females showed no preference between the two substrates. Similar responses were observed in A. ludens by ROBACKER \& Fraser (2002), who showed that females with prior experience of host fruits were more attracted to those fruits than naive females. According to the same authors, females of $A$. ludens with prior experience of Citrus paradisi Macfad. (Rutaceae) fruits were more attracted to an extract of the rind of that fruit in windtunnel experiments than naive females, which showed no preference. Prior experience with the odor of the host plant may be related to the olfactory memory of the insect (RoBACKer \& Fraser, 2005).

As observed in this study with A. fraterculus, experienced females of $A$. ludens visited artificial oviposition substrates treated with agar significantly more than naive females. However, the number of ovipositions did not differ between groups in that study (Díaz-Fleischer \& Aluja, 2003).

The results of this study indicate that prior exposure to certain substrates can increase flies' preference for oviposition sites possessing those same characteristics. It makes possible a improve understanding regarding to strategies of host selection and A. fraterculus oviposition behavior, thus data may assist massal rearing of these insects in laboratory. 

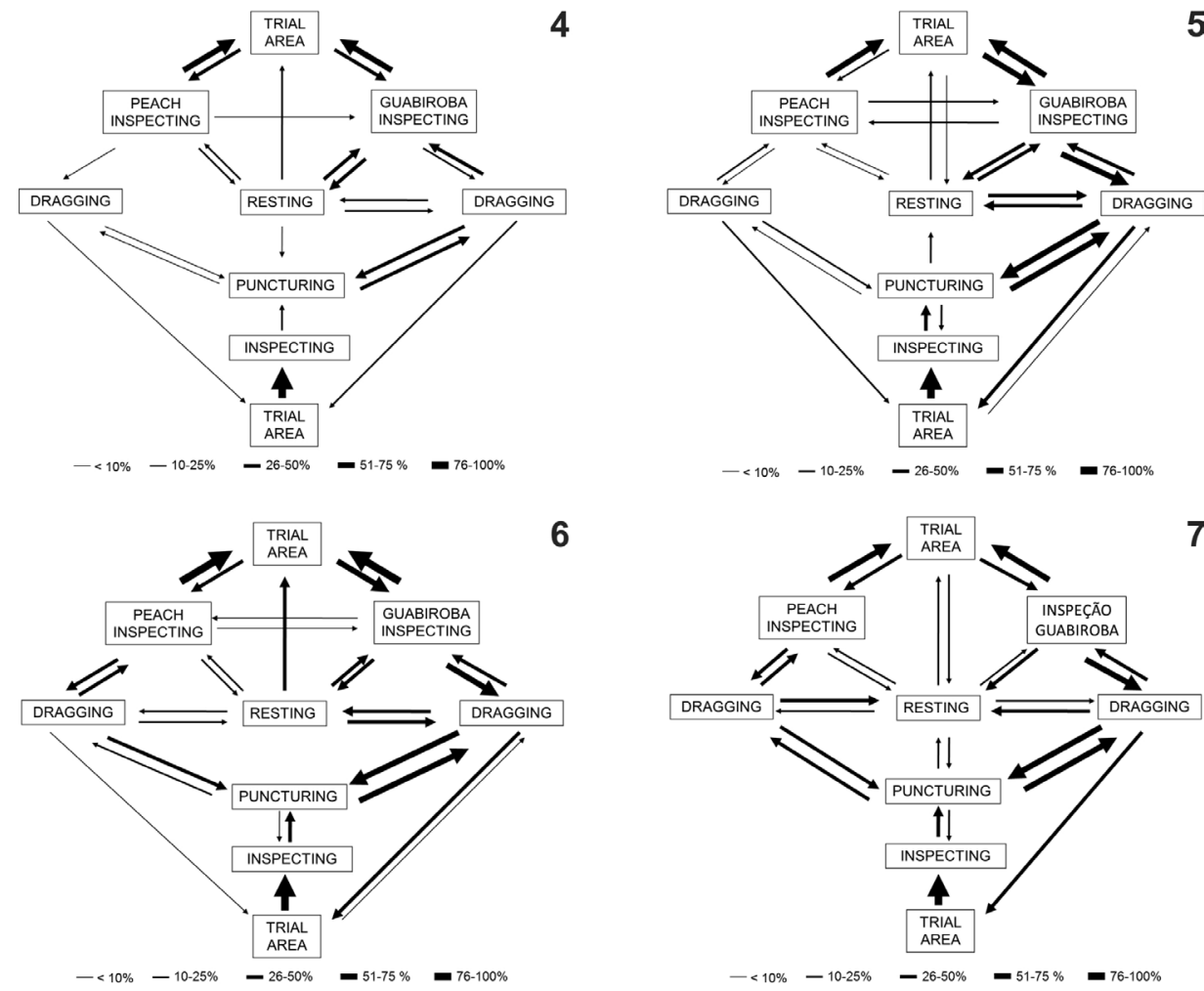

Figs 4-7. Ethograms of Anastrepha fraterculus (Wiedemann, 1830) females: 4, naive (those with no prior contact with the oviposition substrate) exposed to artificial fruits with peach and guabiroba pulp $(\mathrm{n}=18)$. Females which spent the entire trial off the fruits (trial area) are not included $(\mathrm{n}=2) ; 5$, with prior experience of substrates containing guabiroba pulp who were exposed to artificial fruits containing peach and guabiroba pulp $(\mathrm{n}=22)$. Females which spent the entire trial off the fruits (trial area) are not included $(\mathrm{n}=1) ; 6$, females with prior experience of substrates containing peach and guabiroba pulp who were exposed to artificial fruits containing guabiroba and peach pulp $(\mathrm{n}=22) ; 7$, with prior experience of substrates containing peach pulp who were exposed to artificial fruits containing guabiroba and peach pulp $(n=20)$. The thickness of arrows indicates the proportion of insects which showed each behavior.

\section{REFERENCES}

Cornelius, M. L.; Duan, J. J. \& Messing, R. H. 2000. Volatile Host Fruit Odors as Attractants for the Oriental Fruit Fly (Diptera: Tephritidae). Journal of Economic Entomology 93(1):93-100.

Cytrynowicz, M.; Morgante, J. S. \& Souza, H. M. L. 1982. Visual resonses of South American fruit flies, Anastrepha fraterculus, and Mediterranean fruit flies, Ceratitis capitata, to colored rectangles and spheres. Environmental Entomology 11(2):1202-1210.

Díaz-Fleischer, F. \& Aluja, M. 2003. Influence of conspecific presence, experience, and host quality on oviposition behavior and clutch size determination in Anastrepha ludens (Diptera: Tephritidae). Journal of Insect Behavior 16:537-554

Drew, R. A. I.; Prokopy, R. J. \& Romig, M. C. 2003. Attraction of fruit flies of the genus Bactrocera to colored mimics of host fruit. Entomologia Experimentalis et Applicata 107(1):39-45.

Jaldo, H. E.; Ramajo, M. C. G. \& IllinK, E. W. 2001. Mass rearing of Anastrepha fraterculus (Diptera: Tephritidae): a preliminary strategy. Florida Entomologist 84(4):716-718.

Joachim-Bravo, I. S.; Guimarães, A. N. \& Magalhães, T. C. 2001a. Influência de substâncias atrativas no comportamento alimentar e na preferência de oviposição de Ceratitis capitata (Diptera: Tephritidae). Sitientibus, Série Ciências Biológicas 1(1):60-65.

Joachim-Bravo, I. S.; Fernandes, O. A.; Bortoli, S. A. \& Zucoloto, F. S. 2001b. Oviposition preference hierarchy in Ceratitis capitata (Diptera, Tephritidae): influence of female age and experience. Iheringia, Série Zoologia 91:93-100

Katsoyannos, B. I. \& Kouloussis, N. A. 2001. Captures of the olive fruit fly Bactrocera oleae on spheres of different colours. Entomologia Experimentalis et Applicata 100(2):165-172.

Loaiza J. C. M. \& CÉspedes, C. L. 2007. Compuestos volatiles de plantas. Origen, emission efectos, análisis y aplicaciones al agro. Revista Fitotecnia Mexicana 30(4):327-351.
López-Guillén, G.; Valle-Mora, J.; Cazares, C. L. \& Rojas, J. C. 2009. Response of Anastrepha obliqua (Diptera: Tephritidae) to Visual and Chemical Cues Under Seminatural Conditions. Journal of Economic Entomology 102:954-959.

Malavasi, A.; Morgante, J. S. \& Prokopy, R. J. 1983. Distribution and activities of Anastrepha fraterculus (Diptera: Tephritidae) flies on host and nonhost trees. Annals of the Entomological Society of America 76: 286-292.

Malo, E. A.; Cruz-López, L.; Toledo, J.; Del Mazo, A.; Virgen, A. \& RoJAS, A. C. 2005. Behavioral and electrophysiological responses of the Mexican fruit fly (Diptera: Tephritidae) to guava volatiles. Florida Entomologist 88(4):364-371.

McInNIS, D. O. 1989. Artificial oviposition sphere for Mediterranean fruit flies (Diptera: Tephritidae) in field cages. Journal of Economic Entomology 82(5):1382-1385.

Piñero, J. C.; JÁcome, I.; VARgas, R. \& ProKopy, R. J. 2006. Response of female melon fly, Bactrocera cucurbitae to host-associated visual and olfactory stimuli. Entomologia Experimentalis et Applicata 121:261-269.

Robacker, D. C. \& Fraser, I. 2002. Do mexican fruit flies (Diptera: Tephritidae) prefer grapefruit to yellow chapote, a native host? Florida Entomologist 85:481-487.

2005. What Do Mexican Fruit Flies Learn When They Experience Fruit? Journal of Insect Behavior 18:529-542.

SALLeS, L. A. B. 1992. Metodologia de criação de Anastrepha fraterculus (Wied., 1830) (Diptera: Tephritidae) em dieta artificial em laboratório Anais da Sociedade Entomológica do Brasil 21:479-487.

Siderhurst, M. S. \& JANG, E. B. 2006. Attraction of Female Oriental Fruit Fly, Bactrocera dorsalis, to Terminalia catappa Fruit Extracts in Wind Tunnel and Olfactometer Tests. Formosan Entomologist 26:45-55.

Sugayama, R. L. \& Malavasi, A. 2000. Ecologia comportamental, p.103-108. In: Malavasi, A. \& Zucchi, R. A. eds. Moscas-dasfrutas de importância econômica no Brasil: conhecimento básico e aplicado. Ribeirão Preto, Holos. 327p. 